\title{
Andrei V. Sher and his role in Quaternary invertebrate study
}

\author{
S.A. Kuzmina ${ }^{1 *}$, S.A. Elias ${ }^{2}$ \\ ${ }^{1}$ Laboratory of Arthropods, Borissiak Palaeontological Institute, Profsoyuznaya Str. 123, Moscow, \\ 117997, Russia. \\ ${ }^{2}$ Institute of Arctic and Alpine Research, University of Colorado, Boulder 20 UCB Boulder, CO \\ 80309-0020 USA. \\ E-mails: svkuz@yandex.ru,scottelias59@gmail.com
}

ABSTRACT: Andrei V. Sher (1939-2008) is known as a Quaternary palaeontologist, specializing in large mammals, but his contributions to the study of fossil invertebrates (mainly insects) were also great. He was a leader of a small informal scientific group and a member of large network of researchers who studied Beringia with a focus on stratigraphy and paleoenvironmental reconstructions. Different methods, including fossil invertebrate study, were used for these purposes. Sher considered insects to be the key group to develop our understudying of the non-analogue extinct steppe-tundra community. He was the initiator and designer of a digital database for Siberian Quaternary insects (QUINSIB). He applied the MCR method for climate reconstruction in Siberia and used insects for detailed stratigraphic correlations. A.V. Sher worked in both parts of Beringia: northern-east Siberia and Chukotka (Western Beringia) and Alaska and the Yukon (Eastern Beringia); he had the rare gift of being able to observe the whole picture. This issue of "Invertebrate Zoology" is dedicated to A. Sher's 80th anniversary.

How to cite this article: Kuzmina S.A., Elias S.A. 2019. Andrei V. Sher and his role in Quaternary invertebrate study // Invert. Zool. Vol.16. No.2. P.79-88. doi: 10.15298/ invertzool.16.2.01

KEY WORDS: Quaternary, invertebrates, insects, Beringia.

\section{Андрей Владимирович Шер и его роль в изучении четвертичных беспозвоночных}

\section{С.А. Кузьмина ${ }^{1}$, С.А. Элиас ${ }^{2}$}

${ }^{1}$ Лаборатория Артропод, Палеонтологический институт им. А.А. Борисяка, ул. Профсоюзная 123, Москва, 117997, Россия.

${ }^{2}$ Institute of Arctic and Alpine Research, University of Colorado, Boulder 20 UCB Boulder, CO 80309-0020 USA.

E-mails:svkuz@yandex.ru,scottelias59@gmail.com

РЕЗЮМЕ: Андрей Вдадимирович Шер (1939-2008) известен как палеонтолог, специализировавшийся на крупных млекопитающих, но он сыграл также большую роль в изучении ископаемых беспозвоночных (в основном насекомых). Он являлся лидером небольшой неформальной группы, а также участником сообщества ученых, изучающих Берингию, стратиграфию этого региона и природные обстановки прошлого. Для этих целей используются различные методы, в том числе изучение беспозвоночных. А.В. Шер считал, что насекомые являются ключевой группой в развитии теории тундростепи как безаналогового вымершего сообщества. По его 
инициативе и его дизайну была создана компьютерная база данных четвертичных насекомых Сибири (QUINSIB). Он также впервые в Росси применил метод MCR для реконструкции климата в Сибири и использовал насекомых для детальных стратиграфических корреляций. Андрей Владимирович обладал редким даром видеть воспринимать картину древнего континента Беринги целиком, а кроме того, он лично работал как на северо-востоке Сибири (западная Берингия), так и на Аляске и Юконе (восточная Берингия). Этот выпуск журнала “Invertebrate zoology” посвящен его 80летнему юбилею.

Как цитировать эту статью: Kuzmina S.A., Elias S.A. 2019. Andrei V. Sher and his role in Quaternary invertebrate study // Invert. Zool. Vol.16. No.2. P.79-88. doi: 10.15298/ invertzool.16.2.01

КЛЮЧЕВЫЕ СЛОВА: Четвертичный период, беспозвоночные, насекомые, Берингия.

\section{Introduction}

The issue has been compiled as a tribute to the scientist and the man Andrei Vladimirovich Sher (1939-2008). This year - 2019 would have been his $80^{\text {th }}$ anniversary. Although the main specialty of A.V. Sher was the paleontology of large mammals, his contribution to the study of Quaternary invertebrates (mainly insects) was also exceptional . When A.N. Severtsov Institute of Ecology and Evolution, where Andrei worked during the latter part of his career, started to plan a special issue, the original idea was to fit the papers into a single volume of the "Zoologicheskiy Zhurnal". From the inception of this plan, the initial group has received an overflow of responses from Andrei's colleagues. As a result, the issue has had to be divided into two volumes: a vertebrate-focused issue in the "Zoologicheskiy Zhurnal", and a set of invertebrate and stratigraphy papers in "Invertebrate Zoology".

Here we provide a brief summary of Andrei's career, focusing on his substantial influence on Quaternary invertebrate research and the recent development of his ideas. Some authors of the papers of this issue collaborated closely with Andrei, while others followed in the direction he pointed as a scientist.

\section{Beginning of Sher's scientific career}

Andrei Vladimirovich Sher was born on October 28th, 1939 in Moscow; he finished
Moscow high school No. 59 (later No. 58) with a silver medal in 1957; then he attended the Georgaphy Department of Moscow University, beginning in 1962. His love for nature began in his early years. Starting in high school, Andrei did regular scientific work in the "Young Pioneer's House" under the supervision of Boris Bekleshov. This was a well-known group of young researchers, called the "Meshcherskaya Expedition". Andrei became the leader of this group in 1955. Thus, his leadership in scientific research had deep roots.

Andrei received his master's degree based on geomorphology research he performed on the Amguema River, Chukotka (Sher, 1962). His first official job was as a geologist for the Chukotka Hydrogeology Expedition (1962 to 1965 ) with a duty of geological mapping. This work stimulated Andrei's interest in vertebrate palaeontology, based on the numerous fossil bones he found in Chukotka. Because of this, Andrei decided to become a palaeontologist. In 1966 he obtained a postgraduate position in the Geological Institute of the Academy of Sciences of USSR.

After completing his Ph.D. dissertation(Sher, 1969), Andrei worked at the Paleontological Institute of the Academy of Sciences, Moscow, from 1969 to 1983. Here he became head of the "Museum Interior Group" from 1972 to 1975. He worked in A.N. Severtsov Institute of Ecology and Evolution from 1983 until his death in 2008. He continued studying Quaternary mammals of Northern Eurasia. The main geographic 
area of his research was focused on the Kolyma Lowland. Andrei worked in collaboration with scientists from Moscow University, The Geological Institute (Moscow), The Industrial and Research Institute for Construction Engineering (Moscow), The Soil Institute (Pushino, Moscow Area) and others. The core project was the big "Kolymaskaya Expedition" of the Geography Department of Moscow University. During several field seasons, the expedition had a base camp in the small town of Zeleny Mys, not far from the mouth of the Kolyma River. The team worked along the Kolyma River and its tributaries, the Maly Anuy and Omolon Rivers. Another study region was the Yana-Indigirka lowland (the Indigirka River and its tributaries, the Adycha, Chukochya, Alazea, Khomus Yuryakh, Keremesit, and Alazea rivers).

\section{Insect discoveries}

One of the important goals of the expedition was the creation of a regional stratigraphic scheme (Sher et al., 1987). Andrei applied various methods to achieve this. First was a traditional biostratigraphic method based on the evolution of large and small mammals. The small mammal method required wet screening of tons of sediment. Andrei started this work with great enthusiasm. He built a number of screen boxes with $1 \mathrm{~mm}$ wire mesh, and members of the expedition sat for hours near the water, screening sediments with these boxes. The most productive technique involved the use of a water pump, but it was discovered that this setup damaged tiny fossils. Therefore, Andrei chose to use the gentler method of hand screening the sediments in the box (Fig. 1A). His perseverance and attention to details allowed the collection of numerous minute remains in addition to rodent teeth.

Andrei Sher suffered from short-sightedness; he liked to take off his glasses to observe small objects by the naked eye, holding the object near his face. Thus, he was able to see small objects without the need for magnification. Such manipulation allowed him to discover insect remains that were otherwise invisible among the plant debris (Fig. 1B) and the rest of the screened sediment. He immediately understood the importance of his insect fossil discoveries.

Andrei was a man of many talents, including language and communication skills. He spoke English much better than most of his Russian contemporaries; he always read rare foreign publications that were difficult to obtain in the USSR, and he communicated frequently with foreign colleagues. Sher helped build "a bridge" between the Western and Eastern scientific communities studying Beringia (Elias, Dodds, 2011; Kuzmina et al., 2011). For instance, he wrote a letter to John Matthews who worked at the Geological Survey of Canada, asking for his help in identifying insect fossils from northeastern Siberia, based on Matthews' experience in identifying fossil insects from similar Pleistocene deposits in central Alaska (Matthews, 1968). John replied that he recognized some of the beetle remains from Siberia, (mostly circumpolar Carabidae) but that he felt some uncertainty about the identification of some Siberian species (Matthews, 1974).

Andrei wanted to train a Russian scientist to become expert in the identifications of West Beringian insects. Finally, Sergey Kiselev, an entomologist from Ekaterinburg, was invited to take up a Ph.D. position in the Paleontological Institute in Moscow. Sergey had already studied Quaternary insects from West Siberia (Kiselev, 1974) but he collected material for his Ph.D. in the Kolyma Lowland under Sher's supervision. As leader of the expedition, Andrei asked all field teams to screen sediment though $0.5 \mathrm{~mm}$ mesh, especially for insect research. As the result of such collective efforts, S. Kiselev received a huge fossil insect collection. He spent the rest of his life working on this material, and published numerous papers, including two books (Kiselev, 1981, Kiselev, Nazarov, 2009). Sher was the main editor of the Kiselev's first book.

In 1984 Sergei Kiselev invited a student for the purpose of refreshing the fossil collection. He was not able to join the field work himself and needed a helper. In that way the author (SK) 

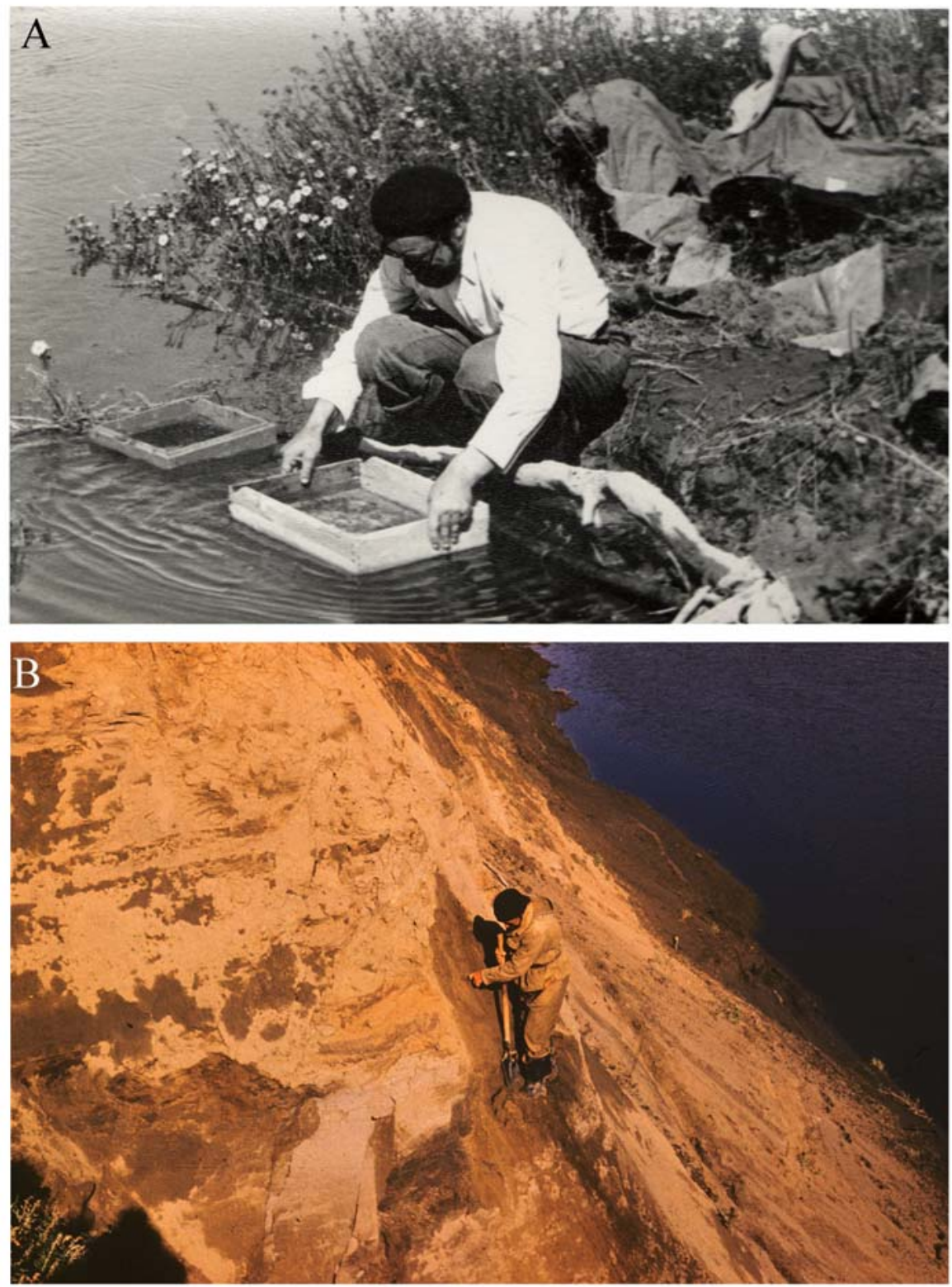

Fig. 1. A - Andrei Sher doing wet screening fossil insects in the Keremesit River, Yana-Indigirka Lowland, 1984; B - A. Sher works on the Middle Pleistocene section, the Keremesit River, 1984.

Рис. 1. А - Андрей Шер промывает ископаемых насекомых в реке Керемесит, Яно-Индигирская низменность, 1984; В - А. Шер работает на разрезе среднего плейстоцена, река Керемесит, 1984.

traveled to the Kolyma Lowland. Later she became a second Western Beringian paleoentomologist. She worked at the Alazea River in 1984 with the team from Moscow University. This team observed traces of the expedition led by Sher on key sections, as he had worked there during the two previous years (Sher, 1981).

During the next summer, SK worked with Andrei himself at the Alazea and Keremesit rivers (Fig. 2A). Field work under Sher's super- 

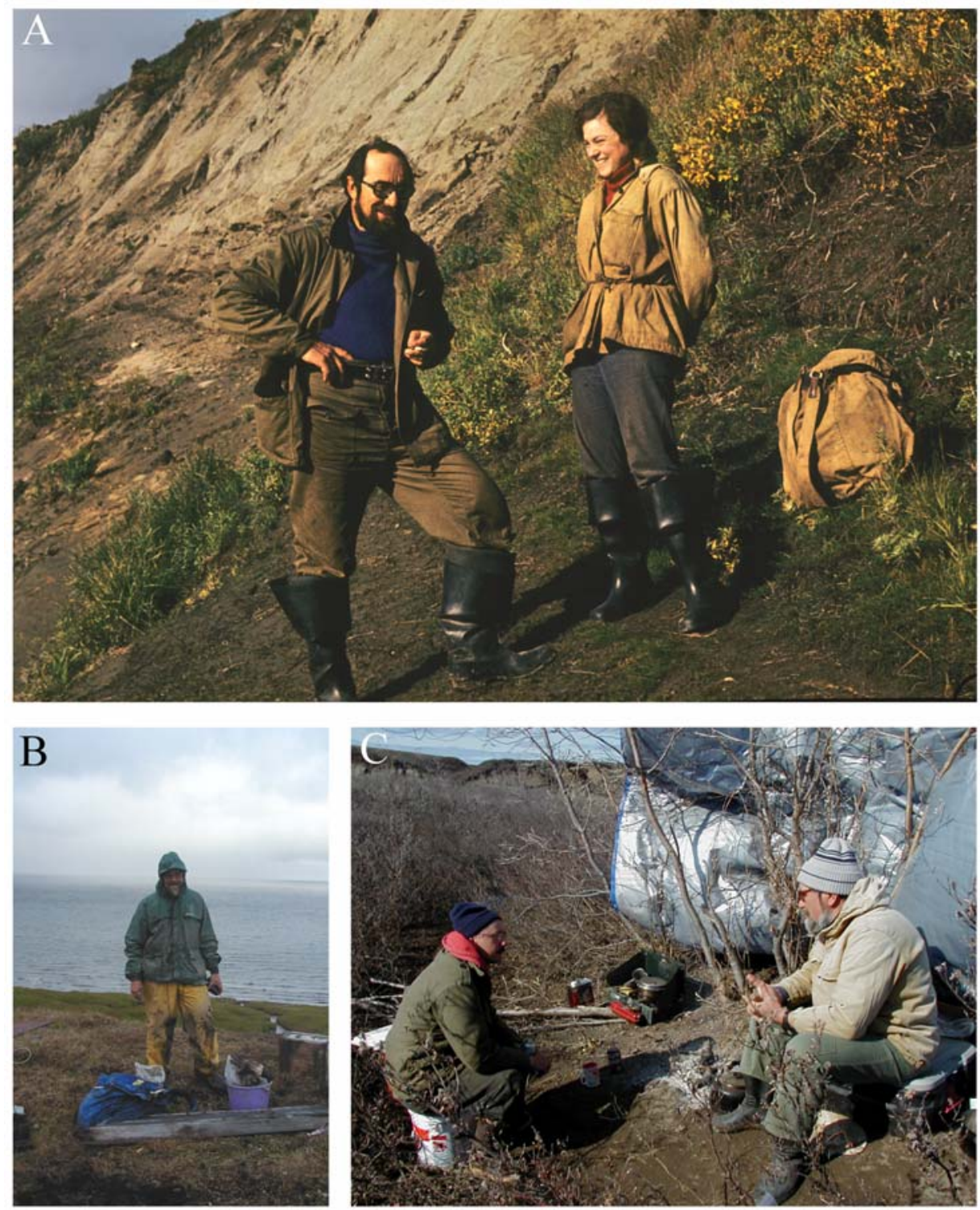

Fig. 2. A - A. Sher and S. Kuzmina, the Keremesit River, 1984; B - A. Sher stands on the top of the Mamontovy Khayata section, Bykovsky Peninsula near Tiksi, 2001; C - A. Sher and P. Matheus discuss the day's results after dinner, at the Titaluk River, North Slope of Alaska, 2003.

Рис. 2. А - А. Шер и С. Кузьмина, река Керемесит, 1984; В - А. Шер на вершине разреза Мамонтовый Хайята, Быковский полуостров недалеко от Тикси, 2001; С - А. Шер и П. Мэтьюз обсуждают результаты рабочего дня после ужина, река Титалук, Северный склон Аляски, 2003.

vision taught her many things. Andrei was a very helpful person. He even tried to stimulate her interest by helping collect modern beetles for her reference collection. Such activities increased his interest in insects.

\section{International cooperation}

Andrei Sher worked hard to develop a WestEast scientific cooperation. The first outstanding event was the Beringian Symposium in 
Khabarovsk in May 1973. The meeting was planned as an All-Soviet Union event, involving of a number of foreign scientists. Andrei was a member of the meeting committee, and he invited foreign colleagues, arranging for simultaneous translation of talks. After the meeting, he was one of the editors of the book "Beringia in the Cenozoic". Since that event, meetings on Beringian science have become a more or less regular tradition.

The next meeting, in 1979, was part the XIV Pacific Science Congress in Khabarovsk. Sher organized the field excursion to the Kolyma Lowland. With the help of colleagues, he wrote a guidebook in both Russian and English (Sher et al., 1979). Each key stratigraphic section was described with maximum details, including the fossil insect data. This was the first attempt to show the importance of insect study in routine Quaternary geology in Russia.

A conference entitles "Paleoecology of Beringia" was held at Burg Wartenstein, Austria, June 8-17, 1979. The conference was sponsored by the Wenner-Gren Foundation for Anthropological Research, The National Geographic Society and the U.S. National Science Foundation. It was organized by David Hopkins of the U.S. Geological Survey, and several colleagues from the United States and Canada. The conference had 27 participants, including five Russians: Genady F. Baryshnikov, Andrei V. Sher, Savely V. Tomirdiaro, Nikolay K. Vereshschagin and Boris A. Yurtsev. In many ways, it was remarkable that these Russian scientists were given permission to travel outside the Soviet Union to attend this conference. The proceedings of the conference were published as a book, "Paleoecology of Beringia" (Academic Press, 1982) edited by David M. Hopkins, John V. Matthews, Jr., Charles E. Schweger, and Steven B. Young.

For many years the coastal regions of Siberia remained closed to outsiders. All visitors, including Russians, were required to obtain a special permit to go there. In 1990 foreign visitors were finally allowed to travel there. Sher decided to establish a regular exchange of Russian and foreign Beringian scientists, in- cluding field excursions in Siberia. One big international expedition visited the classic sections in the Kolyma Lowland in 1990; the next year the group worked in Alaska and the Yukon. Two Canadian paleoentomologists: John Matthew and Alice Telka worked with Andrei in the field.

Andrei took advantage of the opening of the "Iron Curtain". He worked as a visiting professor in the USA and UK and strengthened international cooperation. In 1994 he consulted on the BBC documentary "The Last Mammoth" and accompanied the television crew to the field. The filmmakers visited Wrangel Island where the remains of a middle Holocene-aged mammoth had been discovered. They also visited the Pleistocene sections in the Kolyma Lowland. Andrei wanted to show the typical Quaternary section with frozen loess sediment, ice wedges and numerous bones of large mammals. He also showed the film team how to excavate fossil insects. A huge audience around the world watched Andrei with his screening box and a handful of plant debris with fossil insects inside. Andrei explained the importance of these insects for the reconstruction of mammoth habitat.

The September 1997 Beringian Paleoenvironments workshop in Colorado provided a vehicle for the presentation of the next iteration of Beringian research. The 1997 workshop brought together 88 scientists who came to honor of David Hopkins and his accomplishments in Beringian research. The meeting included 12 Russian scientists. Andrei Sher played a pivotal role in the meeting, providing simultaneous translations of the talks by Russian speakers. The paleoecological and archaeological papers presented at the 1997 workshop gave rise to 20 papers in a special issue of "Quaternary Science Reviews”, spanning many research themes, ranging from lake levels and paleosols to the botanical composition of steppe-tundra and proposed routes of human migration from the Old World to the New.

The next step in international cooperation involving insect studies was the joint RussianGerman project called the "Laptev Sea Sys- 
tem". Sher and Kuzmina were active participants in the coastal part of the project — "Lena Delta 2000". Unfortunately, Andrei became seriously ill in 1998, requiring heart surgery. Nevertheless, he returned to Siberian field work and spent two seasons working on sediments from the Bykovsky Peninsula near Tiksi (Fig. 2B). The project gathered a large quantity of insect data from this new region.

Usually Quaternary insects play a secondary role in stratigraphic reconstructions, but the section at Mamontovy Khayata on the Bykovsky Peninsula became an exception to this. Sher developed a climate curve based on changes in insect faunas through time that aided in the site's age determination (Sher et al., 2005). Insects, especially the presence of the coldadapted weevil Isochnus arcticus, provided evidence of cooling during the first part of last cold stage of the Late Pleistocene (MIS2); but according to the insect assemblages, the second part of MIS2 was much warmer. A similar reconstruction was made on the basis of fossil mammals. Later we recognized a similar insect response to MIS 2 changes in Chukotka (Kuzmina et al., 2011) using the results of a 2004 field trip (Fig.3B).

\section{Insect database}

Russian-German cooperation allowed us to use the facilities of the Otto Schmidt Laboratory in Saint Petersburg, which include a good optical microscope equipped with a camera and computer. Andrei was so satisfied with the quality of insect pictures that he started thinking about developing a fossil insect database. Another prerequisite was a complete list of Quaternary insects from sites in northeastern Siberia, created by Kiselev for his Doctor of Science dissertation (Kiselev, 1995).

The first version of the insect database, LAPPAL, included only the Laptev Sea region (Sher et al., 2000). Later we added old collections of Kiselev and Kuzmina from the Kolyma and Yana-Indigirka Lowlands and from Chukotka. The database changed name to QINSIB (Sher et al., 2006, Kuzmina, 2014). Andrei created the design of this insect database; he wrote the program and did most of the technical work himself. He was the most enthusiastic computer user among all co-authors so he chose to develop QINSIB using Microsoft Access. This program is good for a professional but too complicated for ordinary users. Now SK is trying to make the database easier to use by copying the main lists to Excel spreadsheets.

\section{Temperature reconstructions}

In the late $20^{\text {th }}$ and early $21^{\text {st }}$ centuries, Sher paid increasing attention to paleoenvironmental reconstructions using fossil insects (Sher, Kuzmina, 2000; Sher et al., 2002, 2003, Kuzmina, Sher, 2006). These reconstructions helped him to create a picture of the non-analog steppetundra ecosystem and to explain the Holocene environmental transition (Sher, 1990, 1997a,b). His increasing interest in insects made him known among entomologists. Sher became the author of some insect articles, including a chapter in the "Quaternary Encyclopedia" (Sher, Kuzmina, 2007).

Andrei was very enthusiastic about the Mutual Climatic Range method (MCR). The method allows reconstructions of past temperature (Atkinson et al., 1987; Elias, 1994; Matthews et al., 2019). Sher, with his colleagues Daniil Berman and Arkady Alfimov, suggested that temperatures in the interior of Western Beringia (including exposed continental shelf regions during the coldest stages of the Late Pleistocene were higher than modern temperatures (Alfimov et al., 2003). The Russian version of MCR is different from the traditional one (Alfimov, Berman, 2009); it uses phytophagous insects, which in treeless landscapes were independent from tree-shrub vegetation.

This first attempt of using MCR in Siberia had to be continued. Sher, Kuzmina and A. Sokolov (a PhD student in entomology) wrote a proposal "Reconstruction of Late Pleistocene seasonal temperatures in the Siberian Arctic lowlands based on insect fossils: the mutual climatic range method" for an Otto Schmidt 

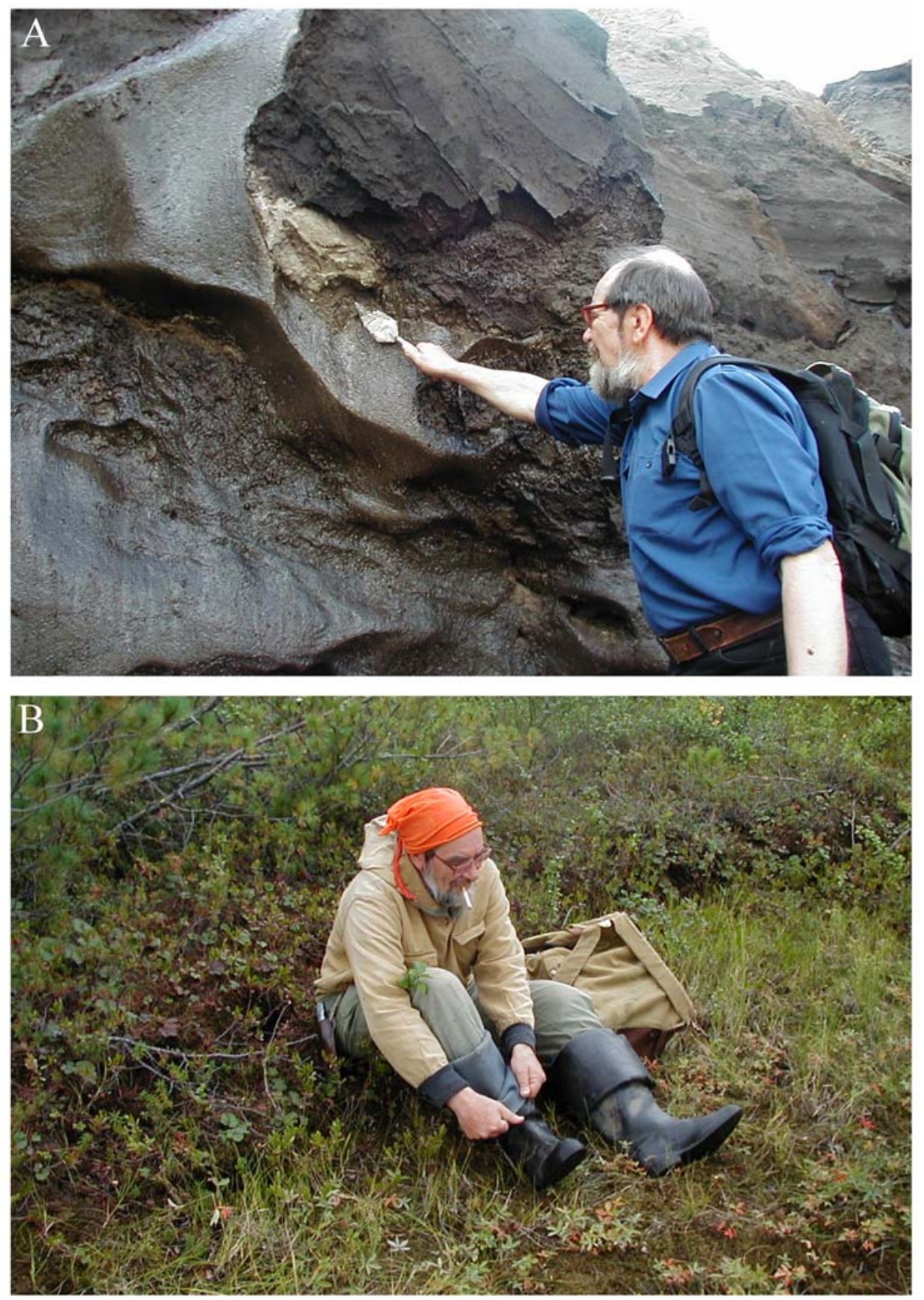

Fig. 3. A - A. Sher looks at a fossil ground squirrel nest in the ice rich Late Pleistocene deposit, the Klondike Gold field, 2003; B - in the Chukotka tundra, 2004.

Рис. 3. А - А. Шер разглядывает ископаемое гнездо суслика в высокольдистых отложениях верхнего плейстоцена, золотоносное поле Клондайка, 2003; В — в чукотской тундре, 2004. 
Laboratory fellowship; they collected modern insect and climate data for this project, but unfortunately this work remains unfinished.

\section{Comparison of the West and East Beringia insects}

Andrei wanted to compare Western and Eastern Beringia insect faunas by means of a study performed by a single investigator. For this purpose, he developed a complicated plan to bring S. Kuzmina to work on tall riverbank exposures in Alaska and the Yukon. The opportunity to carry this out happened in 2003, following the International Mammoth Meeting in Dawson City, Canada (Fig. 3A). Andrei organized another small meeting in Fairbanks that allowed Russian researchers to get American and Canadian visas. After the meetings, A. Sher and Kuzmina went to the field. They worked on the North Slope of Alaska (Titaluk and Ikpikpuk Rivers) and at Tempest Lake on the Seward Peninsula (Kuzmina et al., 2008). The results of North Slope trip (Fig. 2C) are presented in this issue of "Invertebrate Zoology" (Kuzmina et al., 2019).

They spent almost two months in the USA and Canada. The consequences were life changing. S. Kuzmina got two postdoctoral positions to study fossil insects of Alaska and Yukon; the first was in the UK and the second was in Canada. Thus the goal of having a Russian working in Eastern Beringia was achieved beyond expectations.

\section{Conclusion}

Andrei Sher played a major role in the development of insect fossil research in Siberia. Without his efforts, the study of insect remains from Quaternary deposits in northeastern Siberia would never have started or progressed. He greatly stimulated research in this discipline and his work is still bearing fruit today. On August 11, 2008, Andrei suffered a fatal heart attack. We miss him very much.

\section{Acknowledgements}

We thank A. Sher's wife Anna Leirikh, his son Vladimir Sher, his closest colleagues and friends Adrian Lister and Mary Edwards, and many others. Special thank to Alexey Kotov who have arranged this issue of "Invertebrate Zoology" dedicated to the 80th anniversary of A.V. Sher.

\section{References}

Alfimov A.V., Berman D.I. 2009. [Possible errors of the Mutual Climatic Range (MCR) method in reconstructing the Pleistocene climate of Beringia] // Zool. Zhurn. Vol.88. No.3. P.365-377 [in Russian].

Alfimov A.V., Berman D.I., Sher A.V. 2003. [Tundrasteppe insect assemblages and reconstruction of Late Pleistocene climate in the lower reaches of the Kolyma River] // Zool. Zhurn. Vol.82. P.281-300 [in Russian].

Atkinson T.C., Briffa K.R., Coope G.R. 1987. Seasonal temperatures in Britain during the past 22,000 years, reconstructed using beetle remains // Nature. Vol.325. P.587-592.

Elias S.A. 1994. Quaternary insects and their environments. Washington, DC: Smithsonian Institution Press. $284 \mathrm{p}$.

Elias S., Dodds K. 2011. Bridges and bottlenecks: Andrei Sher's role in the development of international collaboration in Beringian science // Quatern. Sci. Rev. Vol.30. P.2049-2053.

Elias S.A., Brigham-Grette B.G. 2001. Beringian paleoenvironments: festschrift in honor of D.M. Hopkins // Quatern. Sci. Rev. Vol.20. P.1-3.

Kiselev S.V. 1973. [The Late Cenozoic Coleoptera of the Transuralia] // Paleontol. Zhurn. Vol.4. P.70-73 [in Russian].

Kiselev S.V. 1981. [Late Cenozoic Coleoptera of NorthEast Siberia]. Moscow: Nauka. 116 p. [In Russian]

Kiselev S.V. 1995. [Northern Eurasia environment in the Pleistocene and Holocene (after Coleoptera insects researches)]. Ph.D. Thesis in Geology. Moscow: Moscow State University. 59 p. [In Russian]

Kiselev S.V., Nazarov V.I. 2009. Late Cenozoic insects of Northern Eurasia// Palaeontol. J., Supplement. Vol.43. No.7. P.1-128.

Kuzmina S. 2014. New approach to the Quaternary studies: QINSIB - the database of Siberian fossil insects // Quatern. Intern. Vol.341. P.283-293.

Kuzmina S.A., Elias S.A., Kotov A.A. 2019. Late Quaternary insects and freshwater invertebrates of the Alaskan North Slope and paleoenvironmental reconstructions in Arctic Alaska // Invertebrate Zool. Vol.16. No.2. P.89-125.

Kuzmina S., Elias S., Matheus P., Storer J.E., Sher A. 2008. Paleoenvironmental reconstruction of the Last Glacial Maximum, inferred from insect fossils from a 
buried soil at Tempest Lake, Seward Peninsula, Alaska // Palaeogeogr., Palaeoclim., Palaeoecol. Vol.267. P. 245-255.

Kuzmina S., Lister A.M., Edwards M.E. 2011. Andrei Sher and Quaternary science // Quatern. Sci. Rev. Vol.30. P.2039-2048.

Kuzmina S., Sher A. 2006. Some features of the Holocene insect faunas of northeastern Siberia // Quatern. Sci. Rev. Vol.25. P.1790-1820.

Kuzmina S.A., Sher A.V., Edwards M., Haile J., Yan E., Kotov A.V., Willerslev E. 2011. The late Pleistocene environment of the Eastern West on the principal section at the Main River, Chukotka // Quatern. Sci. Rev. Vol. 30. P.2091-2106.

Matthews J.V., Jr. 1968. A paleoenvironmental analysis of three Late Pleistocene coleopterous assemblages from Fairbanks, Alaska // Quaestiones Entomol. Vol.4. P.202-224.

Matthews J.V., Jr. 1974. Fossil insects from the Early Pleistocene Olyor suite (Chukochya River Kolymian lowland, U.S.S.R.) // Geolog. Surv. of Canada, Papers. Vol.74-1A. P. 207-211.

Matthews J.V., Jr., Telka A., Kuzmina S.A. 2019. Late Neogene insect and other invertebrate fossils from Alaska and Arctic/Subarctic Canada // Invertebrate Zool. Vol.16. No.2. P.126-153.

Sher A.V. 1962. [Quaternary glaciation of the Amguema Depression and Kanchalan Lowland]. M.Sci. Thesis in Geomorphology. Moscow: Moscow State University. 120 p. [In Russian]

Sher A.V. 1981. [On the age determination of loose deposits in the middle course of the Alazeya River (Kolyma Lowland)] // Doklady AS USSR. Vol.258. No.1. P.179-182 [in Russian].

Sher A.V. 1990. [Actualism and disconformism in the studies of Pleistocene mammals ecology] // Zhurnal Obschey Biologii. Vol.51. No.2. P.163-177 [in Russian].

Sher A.V. 1997a. [Nature restructuring in the East-Siberian Arctic at the Pleistocene-Holocene boundary and its role in mammal extinction and emerging of modern ecosystems (Communication 1)] // Kriosphera Zemli. Vol.1. No.1. P.21-29 [in Russian].

Sher A.V. 1997b. [Nature restructuring in the East-Siberian Arctic at the Pleistocene-Holocene boundary and its role in mammal extinction and emerging of modern ecosystems (Communication 2)] // Kriosphera Zemli. Vol.1. No.2. P.3-11 [in Russian].

Sher A., Alfimov A., Berman D., Kuzmina S. 2002. Attempted reconstruction of seasonal temperature for the Late Pleistocene Arctic Lowlands of north-eastern Siberia based on fossil insects // Sixth QUEEN Work- shop Abstracts, 24-28 May 2002. Switzerland: Spiez. P.50-51.

Sher A.V., Kaplina T.N., Giterman R.E., Lozhkin A.V., Arkhangelov A.A., Kiselev S.V., Kouznetsov Yu.V., Virina E.I., Zazhigin V.S. 1979. Late Cenozoic of the Kolyma Lowland: XIV Pacific Science Congress, Tour Guide XI // Khabarovsk August 1979. XIV Pacific Science Congress. Moscow: Academy of Sciences of the USSR Press. 116 p. [In Russian and English]

Sher A.V., Kaplina T.N., Ovander M.G. 1987. [Unified Regional Stratigraphic Chart for the Quaternary deposits in the Yana-Kolyma Lowland and its mountainous surroundings. Explanatory Note] // N.A. Shilo (ed.). Reshenie Mezhvedomstvennogo Stratigraficheskogo Soveschaniya po chetvertichnoy systeme vostoka SSSR. Magadan, 1982. Magadan: Akademiya Nauk SSSR, Dal'nevostochnoe Otdeleniye. P.29-69 [in Russian].

Sher A., Kuzmina S. 2000. Mosaic arctic grassland, swamp, or barren tundra: problems of the environmental reconstruction of the Ice Complex deposition time // Sixth Workshop on Russian-German Cooperation: Laptev Sea System 2000. St.-Petersburg, Russia. Koln: Terra Nostra. Schriften der Alfred-Wegener-Stiftung. P.70-71.

Sher A., Kuzmina S. 2007. Beetle records/ Late Pleistocene of Northern Asia // S. Elias (ed.). Encyclopedia of Quaternary Science. Amsterdam: Elsevier. Vol.1. P. 246-267.

Sher A.V., Kuzmina S.A., Kiselev S.V., Korotyaev B.A., Alfimov A.V., Berman D.I. 2006. QUINSIB-The Database on Quaternary Insects of North-Eastern Siberia (Preliminary version 2, 02. 06).

Sher A., Kuzmina S., Kiselev S., Lister A., 2003. Tundrasteppe environment in arctic Siberia and the evolution of the woolly mammoth // Occasional Papers in Earth Sciences. Vol.5 (The Third International Mammoth Conference. Program and Abstracts). P.136-142.

Sher A., Kuzmina S., Kuznetsova T. 2000. LAPPAL - the database on the Pleistocene environment of the East Siberian Arctic Shelf (Laptev land paleoecology). Preliminary report // Terra Nostra; Schriften der Alfred-Wegener-Stiftung. Vol.8. P.71-72.

Sher A.V., Kuzmina S.A., Kuznetsova T.V., Sulerzhitsky L.D. 2005. New insights into the Weichselian environment and climate of the Eastern-Siberian Artic, derived from fossil insects, plants, and mammals // Quatern. Sci. Rev. Vol.24. P.533-569.

Responsible editor A.A. Kotov 